\title{
Partial left ventriculectomy in a child: 70-month clinical follow up
}

\author{
Ventriculectomia parcial esquerda em criança: acompanhamento clínico por 70 meses
}

Eduardo COELHO DE SOUZA, Rosangela Belbuche FITARONI, Marcos Dantas de ALMEIDA, Magnus Rosa COELHO DE SOUZA

RBCCV 44205-623

\section{Abstract}

We describe the 70- month follow up of a child with idiopathic dilated cardiomyopathy and end-stage congestive heart failure (NYHA III/IV) who underwent partial left ventriculectomy - the Batista operation when he was two and half years old. The clinical follow up was performed in the outpatient clinic by electrocardiography, echocardiography and radionuclide ventriculography to better analyse the left ventricular ejection fraction. The left ventricular diameter increased. Echocardiograms showed enlargement mainly in the systolic left ventricular diameter and slow decrease in fractional shortening (delta D). The child was in class I (NYHA) during the follow-up. His exercise endurance was better than before surgery and hospitalization was not necessary. For these reasons, we believe that this procedure can be considered as a therapeutic option in children with severe dilated cardiomiopathy who are waiting for heart transplantation, as the shortage of donors is a fact.

Descriptors: Cardiomyopathy, congestive, surgery. Cardiac surgical procedures, methods. Heart ventricle, surgery.

\section{Resumo}

Relatamos a evolução durante 70 meses de uma criança submetida a ventriculectomia parcial esquerda, pela técnica de Batista aos 2 anos e 6 meses de idade, em classe funcional III/IV em decorrência de cardiomiopatia dilatada idiopática, com seguimento clínico ambulatorial. Realizamos eletrocardiogramas, ecocardiogramas seriados e ventriculografia radioisotópica para melhor analisar a fração de ejeção do ventrículo esquerdo. Houve progressivo aumento deste. $O$ ecocardiograma mostrou aumento principalmente do diâmetro sistólico do ventrículo esquerdo com queda progressiva, porém lenta, da fração de ejeção. Apesar da progressão da disfunção miocárdica, a criança manteve-se em classe funcional I durante todo o seguimento, com melhora da tolerância ao exercício e não necessitou de internações. Por isso, achamos que o método pode ser considerado opção terapêutica em crianças com cardiomiopatia dilatada avançada, aguardando a indicação mais tardia de transplante cardíaco, levando-se em conta a dificuldade de órgãos disponíveis para a população pediátrica.

Descritores: Miocardiopatia congestiva, cirurgia. Procedimentos cirúrgicos cardíacos, métodos. Ventrículo cardíaco, cirurgia

\footnotetext{
Work performed in the institute of D.C.P.E.J. Zerbini / Dr. Magnus R. Coelho de Souza

Hospital Beneficência Portuguesa de São Paulo

Correspondence address:

Rosangela Belbuche Fitaroni

Rua Maestro Cardim, n $1218 / 54$, Paraíso, São Paulo-SP

CEP.: 01323-001

Telefone (11) 283.4015 / 289.6730/ 9939.8233

Fax (11) 289.6730

E-mail fitaroni@aol.com
} 


\section{INTRODUCTION}

The treatment of heart failure (HF) is becoming an evergreater challenge, mainly due to the increase in the life expectancy of the population. Without doubt, heart transplantation is the best surgical therapeutic option, but it is only available to a small number of patients due principally to the scarcity of donors. Apart from the clinical therapeutic advances a series of surgical alternatives have been developed, such as cardiomyoplasty $[2,5\}$, circulatory assistance devices, artificial heart and left partial ventriculectomy [1].

The reduction of the left ventricular volume by surgery, was proposed by Batista et al. [1] and this spread to several heart surgery centers around the world. The technique consists of the partial resection of the free wall of the left ventricle (LV) and ventriculorrafy with a continuous double suture using polypropylene 3-0, without reinforcement or anchoring.

We report on a case of a child submitted to this technique and his follow-up of 70 months.

\section{CASEREPORT}

We report on the 70-month clinical follow-up of a child submitted to left partial ventriculectomy at the age of two years and six months [3]. During the clinical evolution the child presented with signs of left ventricular overload (LVO) on the electrocardiogram. Several echocardiograms were made, with varying intervals and a progressive deterioration of the left ventricular ejection fraction (LVEF), delta D and mitral failure (MF) were observed as can be seen in Table 1. The LVEF and the delta $\mathrm{D}$ in the pre-operative period were $14 \%$ and $5 \%$ respectively and increased to $39 \%$ and $18 \%$ in the immediate post-operative period. On the 15 th day after surgery they had increase to $50 \%$ and $18 \%$ arriving at a maximum of $63 \%$ and $28 \%$ in the second post-operative year.

In the seventh month of clinical follow-up, discreet increases in the right atrium (RA) and the right ventricle (RV) were evidenced as was moderate tricuspid insufficiency (TI) which was solved with a reduction of the intake of salt without requiring an increase in the drugs prescribed.

Radioisotopic ventriculography was performed in the pre-operative period, on the 15 th post-operative day and after five years of follow-up and the results are exhibited in Table 1.

The patient continues as Functional class I, without restrictions of physical activities, despite the worsening of the LVEF, using since leaving hospital captopril $(1 \mathrm{mg} / \mathrm{kg} /$ day), furosemid (1 mg/kg/day), digital and potassium replaced by diet. Three months ago carvedilol $(3.125 \mathrm{mg} /$ day) was introduced without expressive modification in the

Table 1. Radioisotopic ventriculography

\begin{tabular}{|c|c|c|c|c|c|c|c|c|c|}
\hline & $08 / 05 / 97 * *$ & $20 / 05 / 97$ *** & $04 / 06 / 97 * * * *$ & 7/1/1998 & 18/8/1998 & $15 / 4 / 1999$ & $15 / 7 / 2000$ & $19 / 4 / 2001$ & $7 / 6 / 2002$ \\
\hline LVDD (mm) & 61 & 42 & 50 & 53 & 52 & 53 & 56 & 58 & 61 \\
\hline $\operatorname{LVSD}(\mathrm{mm})$ & 58 & 37 & 40 & 39 & 37 & 39 & 43 & 44 & 51 \\
\hline $\operatorname{LVEF}(\%)$ & 14 & 39 & 48 & 60 & 63 & 60 & 54 & 56 & 41 \\
\hline delta $\mathrm{D}(\%)$ & 5 & 18 & 20 & 26 & 28 & 26 & 23 & 24 & 16 \\
\hline MI & moderate & minimal & minimal & discrete & discrete & discrete & discrete & discrete & moderate \\
\hline TI & absent & absent & absent & moderate & minimal & minimal & discrete & discrete & discrete \\
\hline $\operatorname{LVEF}(\%) * * * * *$ & 20 & 30 & & & & & & & 22 \\
\hline \multicolumn{10}{|l|}{ Radioisotope } \\
\hline $\begin{array}{l}\text { RVEF }(\%) * * * * * * * \\
\text { Radioisotope }\end{array}$ & 41 & 40 & & & & & & & 38 \\
\hline
\end{tabular}

LVDD (left ventricle diastolic diameter); LVSD (left ventricle systolic diameter); LVEF (left ventricle ejection fraction); MI (Mitral insufficiency); TI (tricuspid insufficiency); RVEF (Right ventricle ejection fraction)

$*$ Cube method $(\mathrm{VN}>65 \%) \quad * *$ pre-operative echocardiogram $\quad * * *$ Immediate post-operative echocardiogram

$* * * *$ Echocardiogram on 15th post-operative day $\quad * * * * * \mathrm{VN}>46 \% \quad * * * * * \mathrm{VN}>40 \%$ 
echocardiographic measurements until now. In the last clinical evaluation, the echocardiogram evidenced a more progressive reduction in the LVEF in relation to the preceding assessment (10 months before), shown in Figure 1.

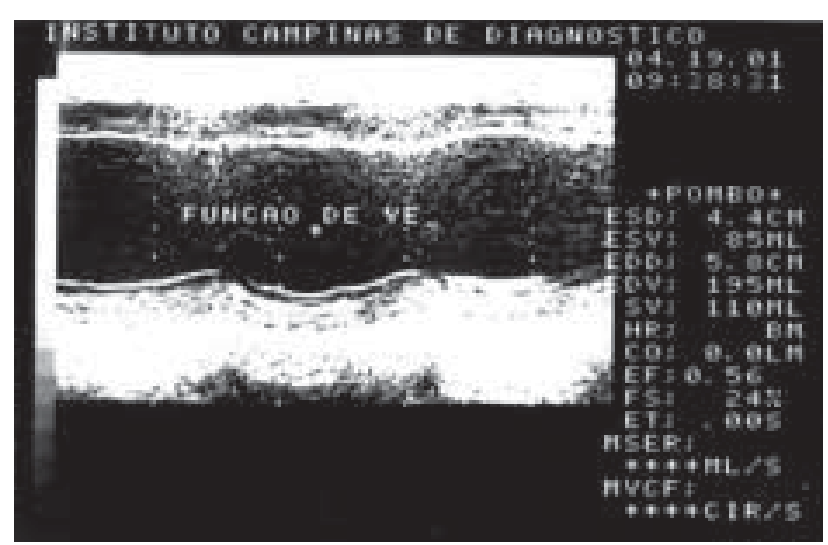

Fig. 1 - Mode $M$ of the ventricles, showing $L V D D=58 \mathrm{~mm}$; LVSD $=44 \mathrm{~mm} ; L V E F=56 \%$ and delta $D=24 \%$

\section{COMMENTS}

In spite of several studies having demonstrated the improvement in the functioning of the LV and the symptoms of HF [4], the results have been controversial, besides the technique presenting with a high early mortality rate by progression the HF or by arrhythmia [4]. The national and international experience with the utilization of left partial ventriculectomy, as an alternative to heart transplantation, in the treatment of patients suffering from dilated cardiomyopathy, currently include more than 1000 cases operated worldwide [6], however the results continue to be controversial.

The survival in the late post-operative period seem to be related according, to a recent work by Moreira et al. [6] to parameters such as: apoptosis of myocardial cells, diameter of the myocardial fibers, functional class, mean pulmonary capillary pressure, LV fractional shortening, plasmatic norepinephrine level and the index of the left ventricle systolic work.

The procedure improves the quality of life, the cardiac dynamics, and sudden death tends to be controlled with the implantation of cardioversor-defibrillators, in selected patients [4]. The challenge is to define the clinical and morphological profile predictive of a good long-term prognosis inferring with this in the selection and results of the surgery [4]. We believe that in children, the procedure is an option to be considered, as besides deferring heart transplantation, it improves the quality of life and tolerance to exercise and in the present case, there was no necessity of post-operative hospitalization.

\section{BIBLIOGRAPHIC REFERENCES}

1. Braile DM, Godoy MF, Thevenard GH et al. Clinical evolving analysis of patients with dilated cardiomyopathy undergoing dynamic cardiomyoplasty. Progr Biomed Res 1996;58-64.

2. Moreira LF, Stolf NA, Bocchi EA, Bacal F, Pêgo-Fernandes $\mathrm{PM}$, Abensur $\mathrm{H}$ et al. Clinical and left ventricular function outcomes up to five after dynamic cardiomyoplasty. J Thorac Cardiovasc Surg 1995; 109:353-63.

3. Batista RJV, Santos JLV, Franzoni M, Araújo ACF, Takeshita $\mathrm{N}$, Furukawa $\mathrm{M}$ et al. Ventriculectomia parcial: um novo conceito no tratamento cirúrgico de cardiopatias em fase final. Rev Bras Cir Cardiovasc 1996; 11:1-6.

4. Elias LM, Monteiro R, Fitaroni RB, Zaninotto M, Souza EC, Rivero MA et al. Ventriculectomia parcial em criança: técnica de Batista. Arq Bras Cardiol 1997; 69:133-5.

5. Frota Filho JD, Lucchese FA, Blacher C, Halperin C, Jawetz J, Lúcio EA et al. Três anos de ventriculectomia parcial esquerda: resultados globais e tardios de 41 pacientes. Rev Bras Cir Cardiovasc 1999; 14:75-87.

6. Moreira LFP, Bacal F, Benício A, Bocchi EA, Higuchi ML, Stolf NAG et al. Fatores prognósticos e evolução da função ventricular em 5 anos de seguimento da ventriculectomia parcial esquerda no tratamento da cardiomiopatia dilatada. Rev Bras Cir Cardiovasc 2001;16:275-88. 